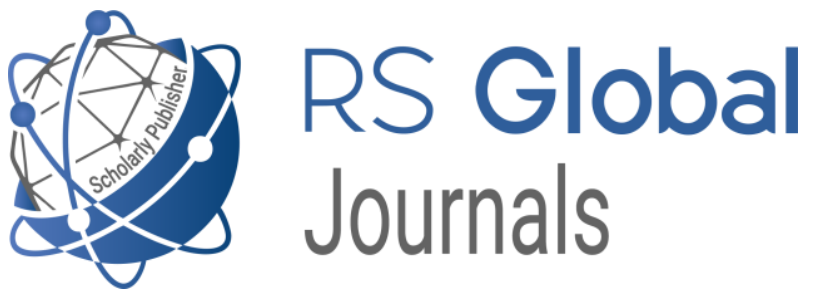

Scholarly Publisher

RS Global Sp. z O.O.

ISNI: 0000000484952390

Dolna 17, Warsaw, Poland 00-773

Tel: +48226022703

Email: editorial_office@rsglobal.pl

JOURNAL International Journal of Innovative Technologies in Social Science

p-ISSN 2544-9338

e-ISSN 2544-9435

PUBLISHER RS Global Sp. z O.O., Poland

ARTICLE TITLE ДОПОМОГОЮ ОБРАЗІВ ПРИРОДНИХ СТИХІЙ НА УРОКАХ УКРАЇНСЬКОЇ ЛІТЕРАТУРИ У 10-11 КЛАСАХ

$\operatorname{AUTHOR(S)\quad ~Орищенко~I.~M.~}$

Orishchenko Inna. (2020) Study of the Style Features of the Literary Works with the Help of Images of Natural Elements ARTICLE INFO During the Lessons of Ukrainian Literature in 10-11 Grades. International Journal of Innovative Technologies in Social Science. 7(28). doi: 10.31435/rsglobal_ijitss/30122020/7296

DOI https://doi.org/10.31435/rsglobal_ijitss/30122020/7296

RECEIVED

30 October 2020

ACCEPTED

14 December 2020

PUBLISHED

19 December 2020

LICENSE

This work is licensed under a Creative Commons Attribution

4.0 International License.

(C) The author(s) 2020. This publication is an open access article. 


\title{
ВИВЧЕННЯ СТИЛЬОВИХ ОСОБЛИВОСТЕЙ ТВОРУ 3 ДОПОМОГОЮ ОБРАЗІВ ПРИРОДНИХ СТИХІЙ НА УРОКАХ УКРАЇНСЬКОЇ ЛІТЕРАТУРИ У 10-11 КЛАСАХ
}

\author{
Орищенко I. М., \\ аспірант кафедри мовно-літературної освіти та культури мови, Ніжинський державний \\ університет імені Миколи Гоголя, м. Ніжин, Украӥна
}

DOI: https://doi.org/10.31435/rsglobal_ijitss/30122020/7296

\section{ARTICLE INFO \\ Received 30 October 2020 Accepted 14 December 2020 \\ Published 19 December 2020}

\section{KEYWORDS}

education, the images of natural elements, teacher, student, stylistic features of the literary works, style, methodological system.

\begin{abstract}
The article is devoted to the problem of studying of the style features of the literary works with the help of images of the natural elements during the lessons of Ukrainian literature in 19-11 grades. In this paper, a new method of studying of the style features is presented. The author of the article defines the aim and basic methodological principles of the research. The aim of the study is to create a theoretical and methodological system that will explore the main stylistic characteristics of the work with the help of images of water, fire, air and earth. The main goal of this research is to analyze the nature of the links between the images of natural elements and stylistic features of a literary work and to develop a methodological system that would allow exploring different levels of the work of art effectively. The images of natural elements play a vital role in studying different levels of the literary works. Previous studies indicate the insignificant role of images of water, fire, air and earth to reveal the stylistic features of the artistic text. However, to the author's ' best knowledge, very few publications are available in the literature that discuss the problem of studying of the style features of the literary works with the help of images of the natural elements. The remainder of the paper is organized into three sections. Section I describes theoretical level of studying the stylistic characteristics of the work through the images of natural elements. Section II analyses features of the reception of images of natural elements by students during the initial reading of the work. Practical results are presented in Section III.
\end{abstract}

Citation: Orishchenko Inna. (2020) Study of the Style Features of the Literary Works with the Help of Images of Natural Elements During the Lessons of Ukrainian Literature in 10-11 Grades. International Journal of Innovative Technologies in Social Science. 7(28). doi: 10.31435/rsglobal_ijitss/30122020/7296

Copyright: (C) 2020 Orishchenko Inna. This is an open-access article distributed under the terms of the Creative Commons Attribution License (CC BY). The use, distribution or reproduction in other forums is permitted, provided the original author(s) or licensor are credited and that the original publication in this journal is cited, in accordance with accepted academic practice. No use, distribution or reproduction is permitted which does not comply with these terms.

Вступ. Урок української літератури є дуже особливим, оскільки він вимагає залучення розумових та емоційних форм мислення від старшокласника. На відміну від інших навчальних предметів, які відтворюють реальні факти та застосовують логічні моделі для вирішення наукової проблеми, література створює дійсність 3 допомогою чуттєвих образів. Кожен художній елемент чи деталь наповнюються певною ідеєю, саме тому основне завдання учителя полягає у створенні таких навчальних моделей та залучення методів, прийомів та стратегій, які б допомогли учню осягнути авторську картину світу, репрезентовану у творі, а також усвідомити ідейну глибину твору. Літературний твір є динамічним утворенням, яке оживає у свідомості під впливом фантазії. «Мистецтво не терпить мертвих форм, холодних, абстрактних, не пройнятих почуттями ідей» [7, с. 139], - зауважує Є. Пасічник. Художній твір повинен спонукати учня до роздумів про власний життєвий шлях, до переосмислення його теперішнього, минулого та майбутнього буття у Всесвіті. Ще однією особливістю уроку української літератури є його виховний потенціал: крім 
набуття теоретичних знань та практичних навичок їх застосування, учитель повинен формувати 3 старшокласника самодостатню особистість 3 самостійними моделями мислення та чіткими моральними орієнтирами.

Аналіз художніх творів повинен висвітлювати усю багатогранність твору у єдності його змісту та форми, розуму та почуття, розкривати різні художні рівні тексту (стильові, жанрові, мовні). Текст є завжди вписаним у певний контекст, позначений впливом певного стилю, жанру чи філософської думки. Старшокласники мають усвідомити, що кожен твір існує не ізольовано, самостійно, а є частиною певної системи, тобто стилю, вбирає його основні риси та світоглядні установки. Образи води, вогню, повітря та землі є змістовим ядром, яке ввібрало у себе базові характеристики певного стилю та допомагають глибше осягнути його стиль та неповторність.

Матеріали та методи. Методологічну основу нашого дослідження складають філософські погляди про існування первообразів, тобто архетипів К. Г. Юнга та уявлення про існування чотирьох першостихій Г.Башляра та Н. Фрая. Г. Башляр пропонує аналізувати літературні твори та творчість письменників на основі вчення про існування чотирьох природних стихій: води, повітря, вогню та землі. Дослідник у книзі «Митець на службі у стихій» наголошував на важливості їх впливу на творчий потенціал особистості: «Стихії - вогонь, повітря, земля, вода, які уже здавна допомагали уявити філософам досконалість світобудови, залишаються й першоосновами художньої творчості» [2, с. 200]. Він вважає, що ці природні стихії виявляють себе через певний набір якостей, характеристик та станів. Філософ був переконаний у тому, що певна сила природи підпорядковує собі хід думок, уяву, фантазію, переконання, погляди, почуття та ідеали людини впродовж всього періоду іiі існування. Н. Фрай вводить архетипні образи води та вогню. Вогонь та світло пов'язані із очищенням, святістю та переродженням, у той час як вода символізує хаос та розщеплення. Стихія вогню відсилає до таких образів як фенікс, еліксир, лотос, сонцем, троянда, вино чи кров.

Об'єкт дослідження - аналіз стильових особливостей твору 3 допомогою образів стихій природи.

Предмет дослідження - теоретико-методологічні засади вивчення стильових особливостей твору з допомогою образів природних стихій на уроках української літератури у 10-11 класах.

Мета дослідження полягає у створенні теоретико-методологічної розробки, яка дозволить досліджувати основні стильові характеристики твору за допомогою образів води, вогню, повітря та землі.

Результати дослідження. Особливості застосування компонентів 3 образними стихійними утвореннями допомагають розкрити стильові характеристики епічного твору. Старшокласники повинні оперувати такими теоретичними відомостями про функцію образів природних стихій для стильового аналізу літературного тексту: модерна література використовує образи води, вогню, повітря та води для представлення внутрішнього світу особистості, їі емоцій, переживань та виявлення психологічних зв'язків, які поєднують людську душу з природою: навколишня дійсність є джерело натхнення та життєвої енергії (психологічна новела «Intermezzo» М. Коцюбинського, новела «Момент». В. Винниченка), крім того вона тяжіє до залучення несвідомих виявів та чинників, які намагається пояснити 3 допомогою образів природних стихій (новела «Новина» В. Стефаника). У творах модерної літератури використовуються язичницьких образів та символів, які репрезентуються через образи природних першоелементів та відображають національні та загальнокультурні концепти (драма-феєрія «Лісова пісня» Лесі Українки, повість «Тіні забутих предків» М. Коцюбинського). Так, неоромантична література прагнула проникнути у трансцендентний світ та пізнати механізм внутрішніх душевних переживань особистості з допомогою архетипної образності, язичницьких символів та міфологізму (повість «Земля» О. Кобилянської, драмафеєрія «Лісова пісня» Лесі Українки). Образи води, вогню, повітря та землі персоніфікуються та стають самостійними дійовими особами, що провокує певні інновації в оповідній формі та часопросторових характеристиках твору (умовність зображення, розмитість часових та просторових рамок, надчасовість та позапросторовість дій) (поема в прозі «Поза межами болю» О. Турянського, кіноповість «Зачарована Десна» О. Довженка та автобіографічний роман «Майстер корабля» Ю. Яновського).

Сформувати такі теоретичні знання можливо за рахунок чітко розробленої послідовності кроків, які сприятимуть набуттю учнями практичних навичок аналізу художнього стилю з допомогою образів води, вогню, повітря та землі. 
Теоретичний рівень. Літературні твори у старшій школі вивчаються не ізольовано, а у контексті культурно-історичних передумов, тенденцій чи модних віянь. Письменник не $\epsilon$ стороннім споглядачем: він вбирає провідні думки та ідеї свого історичного періоду і творить літературний процес. Саме тому старшокласники повинні вміти окреслювати головні філософсько-світоглядні проблеми певного історичного періоду та знаходити їх відображення у текстах письменників. Значну роль у вирішенні цього завдання відіграють образи стихій природи: вони $є$ основним смисловим ядром, яке допомагає глибше розкрити суть того чи іншого літературно-мистецького стилю. Основне завдання теоретичного етапу:

- поглибити знання учнів про поняття «стиль» та різні його види;

- розкрити культурно-історичні причини його виникнення;

- визначити особливості репрезентації кожного окремого стилю, як самобутньої мистецької системи 3 властивими лише їй зв'язками, проблематикою, тематикою та світоглядною системою;

- виявити концептуальні значення, яких набувають образи води, вогню, повітря та землі у різних стильових системах.

Рещептивний рівень. Підготовка до сприймання художнього твору повинна посідати чільне місце на уроці української літератури, адже саме вона створює необхідну емоційну атмосферу, налаштовує на сприймання тексту, сприяє виникненню позитивних інтенцій, викликає інтерес та налаштовує учнів на роботу. Основне завдання педагога - створити позитивну установку в учня, яка б змусила його прочитати його та повноцінно осягнути. Для того, щоб скерувати пізнавальний потенціал старшокласників у потрібне русло, а процес сприймання набув цілеспрямованих та продуктивних рис, учитель повинен запропонувати їм випереджальне завдання, яке може бути репрезентоване у формі опитувальника, проблемного запитання, пам'ятки, презентації, залучення досягнень інших видів мистецтва. Наприклад:

Пам'ятка:

- читайте літературний твір уважно, повність та детально;

- знайдіть незрозумілі слова та встановіть їх значення з метою усунення помилкового розуміння змісту тексту;

- не оминайте поза сюжетних елементів таких, як описи, пейзажі, авторські відступи;

- знайдіть образи води, вогню, повітря та землі;

- визначте основні характеристики певного стилю;

- як реалізуються той чи інший стиль через образи природних елементів: міфологізація, експресія, імпресія, натуралізація, надмірна емоційність і т. д.

Учитель може запропонувати такі презентацій для розкриття стильових особливостей твору: «Імпресіоністичні риси стихій природи у повісті «Тіні забутих предків» М. Коцюбинського» або «Вода, вогонь, повітря та земля: неоромантизм драми-феєрії «Лісова пісня» Лесі Українки».

Вивчаючи імпресіонізм та його основні риси педагог повинен акцентувати увагу учнів на важливості природи та зокрема стихій води, вогню, повітря та землі для митцівекспресіоністів. Для досягнення цієї мети він може провести паралель із образотворчим мистецтвом і використати для цього картини художників-імпресіоністів К. Моне, Ж. Базиль, В. ван Гога та ін.

Аналітичний рівень. Запропоновані учителем принципи та прийоми аналізу твору повинні формувати 3 учнів кваліфікованих читачів 3 важливими для них уміннями та навичками усвідомленого сприймання твору, яке включає в себе розгляд ідейно-тематичного поля та стильової природи через образи природних елементів. Педагог повинен розвивати в старшокласників літературознавчий хист, здатність глибоко, якісно та цілісно усвідомити текст. Завдяки аналізу сюжетних характеристик твору з допомогою образів води, вогню, повітря та землі учитель зможе уникнути поверховості розуміння твору учнями та забезпечить їх якісними знаннями. Вивчення художнього тексту слід розпочати із з'ясування основних рис того чи іншого стилю. Педагогу важливо уникати надмірної термінологізації та уникати незрозумілих для учнів понять, які зроблять навчальний матеріал занадто сухим та нецікавим для старшокласників. Запропонована інформація повинна подаватися доступною для цієї вікової групи мовою. Специфіка уроку української літератури полягає у його емоційності та естетичності, саме тому доцільним буде застосування музичних композицій чи зразків образотворчого мистецтва для 
створення необхідної емоційної атмосфери або використання завдання, яке вимагає від учня виявити його власне ставлення до цього мистецького явища. Важливо, щоб навчальний матеріал, який розглядається на уроці, став власним надбанням старшокласника, досягти цього можливо лише тоді, коли він зможе доторкнутися до найтонших струн його душі та залишити там слід. Основною рушійною силою навчального процесу є мотивація, тобто виникнення потреби в учня до набути знань про певний мистецький стиль та значення образів природних елементів для його вираження. Учитель повинен створити комфортні умови для вираження думки кожним учнем та толерантне ставлення до поглядів, які відрізняються від інших. Урок української літератури - це колективне пізнання важливих істин, відкриття чогось нового та набуття практичних навичок їх пошуку, аналізу та усвідомлення. Вивчаючи твір на уроці української літератури педагогу слід пам'ятати про цілісність його аналізу у єдності змісту та форми, саме тому дослідження стильового рівня тексту через образи води, вогню, повітря та землі у перспективі повинно виходити на виявлення авторської позиції та підтексту. Доцільність запропонованого маршруту пізнання твору обумовлюється пізнанням учнями логіки авторської побудови тексту, тобто вони мають переконатися в тому, що окремі рівні твору існують не ізольовано один від одного, а взаємодіють і формують завершений зразок мистецтва.

Досліджуючи стильові риси твору учитель може обрати індуктивний (через знаходження образів стихій природи та виявлення в них рис певного стилю), дедуктивний методи пізнання (через виокремлення основних стильових характеристик та знаходження їх у внутрішньому просторі тексту) або метод проблемного викладу матеріалу (проблемне запитання, яке задається на початку уроку і вирішується у ході колективного обговорення).

Учні повинні набути таких компетентностей:

- визначати стильові особливості твору через образи води, вогню, повітря та землі;

- пояснювати основні причини їх виникнення та виявляти світоглядні концепти, які генерували появу того чи іншого мистецького стилю;

- усвідомлювати логіку побудови тексту, продиктовану його стильовими особливостями.

Вивчення стилю художнього твору може відбуватися за заздалегідь запропонованими запитаннями, які допоможуть скерувати старшокласників у правильне русло та акцентувати їх увагу на ті аспекти тексту, яким вони можуть не надати належного значення, але, які відіграють істотну роль у процесі осягнення певного стилю, авторської картини світу та підтексту. Педагог може запропонувати учням випереджальне завдання, яке вони мають виконати вдома: пошук цитат та їх коментування, складання логічного ланцюжка i т.д. Такий прийом дозволить зекономити час на уроці та приділити більше уваги встановленню логічних зв'язків між образами води, вогню, повітря, землі та літературним стилем, а також дасть можливість почути художній текст ще раз, відчути його високу естетичну цінність та оцінити майстерність авторського стилю.

Висновки. Отже, образи природних елементів $є$ універсальним засобом пізнання художнього твору та окремих його рівнів, який розкриває різні грані тексту та допомагає глибше осягнути унікальність авторської картини світу та багатство філософського підтексту.

\section{ЛІТЕРАТУРА}

1. Антологія світової літературно-критичної думки ХХ століття / За ред. М.Зубрицької (1996). Львів: Літопис, 634 с.

2. Башляр Г. (1998) Вода и грезы / Пер. с франц. Б.М. Скуратова. Москва: Издательство гуманитарной литературы, 268 с.

3. Башляр Г. (1999) Грезы о воздухе. Опыт о воображении движения / Пер. с франц. Б.М. Скуратова. Москва: Издательство гуманитарной литературы, 344 с.

4. Башляр Г. (2000) Земля и грезы воли / Пер. с франц. Б. М. Скуратова. - Москва: Издательство гуманитарной литературы, 384 с.

5. Башляр Г. (1993) Психоагнализ огня / Пер. с франц. Б.М. Скуратова. Москва: Прогресс, 176 с.

6. Бондаренко Ю. (2012) Методика шкільного вивчення сюжетно-композиційної організації епічного твору: теорія і практика / Ю. Бондаренко. Ніжин: НДУ ім. М. Гоголя, 143 с.

7. Пасічник Є. А. (2000) Методика викладання української літератури в середніх навчальних закладах: Навчальний посібник для студентів вищих закладів освіти. Київ: Ленвіт, 384 с.

8. Юнг К. Г. (1996) Душа и миф: шесть архетипов / К. Г. Юнг. Киев: Государственная библиотека Украины для юношества, 384 с. 